\title{
Impact of Soil Salinity on the Cowpea Nodule-Microbiome and the Isolation of Halotolerant PGPR Strains to Promote Plant Growth under Salinity Stress
}

\author{
Salma Mukhtar, ${ }^{1,2}$ Ann M. Hirsch, ${ }^{1,3, \dagger}$ Noor Khan, ${ }^{1}$ Kauser A. Malik, ${ }^{2}$ Ethan A. Humm, ${ }^{1}$ Matteo Pellegrini, ${ }^{1,3}$ Baochen Shi, ${ }^{4}$ \\ Leah Briscoe, ${ }^{5}$ Marcel Huntemann, ${ }^{6}$ Alicia Clum, ${ }^{6}$ Brian Foster, ${ }^{6}$ Bryce Foster, ${ }^{6}$ Simon Roux, ${ }^{6}$ Krishnaveni Palaniappan, ${ }^{6}$ \\ Neha Varghese, ${ }^{6}$ Supratim Mukherjee, ${ }^{6}$ T.B.K. Reddy, ${ }^{6}$ Chris Daum, ${ }^{6}$ Alex Copeland, ${ }^{6}$ Natalia N. Ivanova, ${ }^{6}$ Nikos C. Kyrpides, ${ }^{6}$ \\ Nicole Shapiro, ${ }^{6}$ Emiley A. Eloe-Fadrosh, ${ }^{6}$ Maskit Maymon, ${ }^{1}$ Muhammad S. Mirza, ${ }^{7}$ and Samina Mehnaz $^{2}$ \\ ${ }^{1}$ Department of Molecular, Cell \& Developmental Biology, University of California-Los Angeles (UCLA), 621 Charles Young Drive South, Los \\ Angeles, CA 90095-1606, U.S.A. \\ ${ }^{2}$ School of Life Sciences, Forman Christian College (A Chartered University), Ferozepur Road, Lahore 54600, Pakistan \\ ${ }^{3}$ Molecular Biology Institute, UCLA, 621 Charles Young Drive South, Los Angeles, CA 90095-1606, U.S.A. \\ ${ }^{4}$ Department of Molecular and Medical Pharmacology, UCLA David Geffen School of Medicine, UCLA, 621 Charles Young Drive South, Los \\ Angeles, CA 90095-1606, U.S.A. \\ ${ }^{5}$ Department of Bioinformatics, UCLA, 621 Charles Young Drive South, Los Angeles, CA 90095-1606, U.S.A. \\ ${ }^{6}$ DOE Joint Genome Institute, Lawrence Berkeley National Laboratory, 1 Cyclotron Road, Berkeley, CA 94720, U.S.A. \\ ${ }^{7}$ Environmental Biotechnology Division, National Institute for Biotechnology and Genetic Engineering (NIBGE), Jhang Road, Faisalabad, Pakistan
}

Accepted for publication 16 July 2020.

\section{ABSTRACT}

Cowpea is one of the major legumes cultivated in arid and semiarid regions of the world. Four soil-microbial samples (SS-1 through SS-4) collected from semiarid soils in Punjab, Pakistan were planted with cowpea (Vigna unguiculata) crops, which were grown under salinity stress to analyze bacterial composition in the rhizosphere and within nodules using cultivation-dependent and -independent methods. Two varieties, 603 and the salt-tolerant CB 46 , were each inoculated with or without the four different native soil samples or grown in medium either $\mathrm{N}$-deficient $(-\mathrm{N})$ or supplemented with $\mathrm{N}(+\mathrm{N})$. Plants inoculated with soil samples SS2 and SS-4 grew better than plants inoculated with SS-1- and SS-3 and grew comparably with the $+\mathrm{N}$ controls. Environmental DNA (eDNA) was isolated from SS-1 and SS-4, and, by $16 \mathrm{~S}$ ribosomal RNA sequencing, the soil microbiomes consisted mainly of Actinobacteria, Firmicutes, Proteobacteria, and other nonproteobacterial genera. However, analysis of eDNA isolated from cowpea nodules established by the trap plants showed that the nodule microbiome consisted almost exclusively of proteobacterial sequences, particularly species of Bradyrhizobium. Bacteria were isolated from both soils and nodules, and 34 of the 51 isolates tested positive for plant-growthpromoting rhizobacteria traits in plate assays. Many could serve as future inocula for crops in arid soils. The discrepancy between the types of bacteria isolated by culturing bacteria isolated from surface-sterilized cowpea nodules (proteobacteria and nonproteobacteria) versus those detected by sequencing DNA isolated from the nodules (proteobacteria) from cowpea nodules (proteobacteria and nonproteobacteria) versus those detected in the nodule microbiome (proteobacteria) needs further study.

Keywords: cowpea microbiome, halotolerant plant-growthpromoting bacteria/rhizobacteria, metagenomics, microbiome, natural habitats, salinity stress, symbiosis
${ }^{\dagger}$ Corresponding author: A. M. Hirsch; ahirsch@ucla.edu

Author contributions: All authors contributed to the development, writing, and completion of this manuscript. A first draft of the manuscript was submitted as part of the Ph.D. degree research of S. Mukhtar at Forman Christian College (A Charter University) in Lahore, Pakistan, under the direction of K. Malik and S. Mehnaz.

Funding: Support was provided by the Higher Education Commission, Pakistan for an IRSIP fellowship at the Department of Molecular, Cell and Developmental Biology, University of California-Los Angeles. Work conducted by the U.S. Department of Energy Joint Genome Institute, a DOE Office of Science User Facility, is supported by the Office of Science of the U.S. Department of Energy (DOE) under Contract Number DE-AC02-05CH11231. A Community Sequence Project (CSP 1571) from the U.S. DOE Joint Genome Institute also funded the project. Additional funding for studying arid soils came from the Shanbrom Family Foundation to A. M. Hirsch.

*The $e$-Xtra logo stands for "electronic extra" and indicates that supplementary materials are published online.

The author(s) declare no conflict of interest.

(C) 2020 The American Phytopathological Society 
Globally, approximately $41.3 \%$ of Earth's surface is affected by salt and drought, and this area continues to expand because of global climate change. A further increase in the percentage of abiotically stressed land will even more adversely affect the ability of the world's population to grow enough food (Huang et al. 2016). Cowpea (Vigna unguiculata) is an important legume crop that is cultivated in arid and semiarid regions of the world. It is a staple for millions of people and a major source of protein and carbohydrate, especially in lesser-developed regions of Asia and Africa. It is not only rich in nutrients but also a good source of antioxidants, dietary fibers, polyphenols, and polyunsaturated fatty acids (Phillips et al. 2003; Shetty et al. 2013; Trinidad et al. 2010).

Cowpea (cultivar Lobia) is one of the most important legumes cultivated in semiarid regions of Pakistan. It is produced and consumed by subsistence farmers, particularly in the barani (dry farming) zones in Pakistan. A multipurpose crop, cowpea is used as a pulse, forage, and vegetable crop (Imran et al. 2012; Muhammad et al. 1993), and also plays an important role in crop rotation systems and restoration of soil fertility through nitrogen fixation. Environmental factors-air temperature, soil salinity, moisture content, soil fertility, and photoperiod length—all have a significant influence on growth and yield of cowpea (Ali et al. 2004). To ensure that cowpea remains a key crop as the climate changes and potentially disrupts dryland farming, the agriculture department of Punjab, Pakistan is importing exotic cowpea varieties and running plant trials under Pakistan conditions in indigenous soils.

Rhizobia are soil-inhabiting Gram-negative bacteria (Proteobacteria) that initiate root nodule development on legume plants, where they are maintained as intracellular symbionts within the nodules. There, they convert atmospheric nitrogen into ammonia for assimilation by the plant in exchange for plant-derived organic acids (Garg and Geetanjali 2007; Graham 2008; Sulieman and Tran 2014). The majority of bacteria that fix nitrogen in root nodules of leguminous plants are members of the class $\alpha$-Proteobacteria and genera Rhizobium, Bradyrhizobium, Ensifer, Phyllobacterium, Mesorhizobium, Devosia, Azorhizobium, Allorhizobium (Hirsch 1992; Lafay and Burdon 2007; Sawada et al. 2003), and Microvirga (Ardley et al. 2012). Members of the family Burkholderiaceae, class $\beta$-Proteobacteria, known as $\beta$-rhizobia, also nodulate legumes (Bontemps et al. 2010; Estrada de los Santos et al. 2018; Gyaneshwar et al. 2011).

A vast literature on microbes other than rhizobia detected within nitrogen-fixing nodules has accumulated, starting with earliest report made by Beijerinck (1888), who described the isolation of brown and yellow-colored Bacillus strains from root nodules. Since then, culture-dependent studies have pointed to a much higher diversity of bacteria associated with root nodules beyond rhizobia. Many of these bacteria do not fix nitrogen and are outside the Proteobacteria phylum (Aserse et al. 2013; Deng et al. 2011). These bacteria have been called nonrhizobial endophytes (NRE) or nodule-associated bacteria (Velázquez et al. 2013), and include the genera Bacillus, Enterobacter, Agrobacterium, Acinetobacter, Paenibacillus, Pantoea, Mycobacterium, Micromonospora, and Pseudomonas (Martínez-Hidalgo and Hirsch 2017). They are not involved in nodule formation per se but many have plant-growthpromoting abilities, including phytohormone production or mineral solubilization activity ( $\mathrm{P}$ and $\mathrm{Zn}$ ) either by themselves or when coinoculated with rhizobia and other bacteria (Gupta et al. 2015; Schwartz et al. 2013). Most of the NRE are not pathogenic but some may be serious pathogens of animals or plants; for example, Staphylococcus and Bordetella spp. (Sturz et al. 1997; Xu et al. 2014) and species of family Burkholderiaceae such as Burkholderia cepacia (Eberl and Vandamme 2016). In the last few years, many of the symbiotic Burkholderia spp. (Gyaneshwar et al. 2011) have been placed into new genera (e.g., Paraburkholderia and Trinickia) (Estrada de los Santos et al. 2018; Sawana et al. 2014).

Although semiarid regions in Pakistan have a large biodiversity of rhizobial resources, only a few of them have been extensively studied by molecular approaches and, thus, the microbial diversity of cowpea-nodulating rhizobia and associated nodule bacteria in semiarid soils remains largely unexplored. Our goal was to assess the effect of native soil microbial communities on the composition of the cowpea nodule microbiome under various salinity conditions. We predicted that we would find bacteria with plant-growthpromoting characteristics in addition to rhizobia within cowpea root nodules inoculated with soil from Pakistan, and that these aridsoil-adapted strains could enhance the rhizobia-legume interaction under climate-change conditions.

\section{MATERIALS AND METHODS}

Soil sampling and physicochemical analysis. Mandi Bahauddin, a fertile agricultural area where the main crops are wheat, maize, sugarcane, chickpea, cowpea, and tobacco, is a district of Punjab, Pakistan. It is situated at $32^{\circ} 35^{\prime} 10^{\prime \prime} \mathrm{N}, 73^{\circ} 36^{\prime} 12^{\prime \prime} \mathrm{E}$ and is outlined in the northwest by the Jhelum river and in the southeast by the Chenab River (Supplementary Fig. S1). Cowpea fields that covered an area of approximately $1.5 \mathrm{~km}^{2}$ made up the study site, and the sampling areas were selected according to land use and vegetation cover. The upper $10 \mathrm{~cm}$ of soil was collected from four sites that were approximately $1 \mathrm{~km}$ apart from each other. The soil sample for each individual site was derived from five different randomly selected plants and thoroughly mixed, yielding a composite sample from sites 1 to 4 (SS-1 to SS-4), which was used for physicochemical analysis (Supplementary Table S1) and preliminary plant tests. From each of the four sampling sites (soil samples SS-1 to SS-4), the soil was gathered from the cowpea rhizospheres by gently removing the plants and obtaining the soil attached to the roots. In total, $1 \mathrm{~kg}$ of the soil from each of the four sites was sent to the University of California-Los Angeles (UCLA) for larger scale plant tests.

Soil physical and chemical properties were determined for SS-1 through SS-4 based on $400 \mathrm{~g}$ of the dried and sieved soil (2-mm sieve size) (Supplementary Table S1). Electrical conductivity $(\mathrm{dS} / \mathrm{m})$ was measured by $1: 1(\mathrm{wt} / \mathrm{vol})$ soil/water mixtures at $25^{\circ} \mathrm{C}$ (Adviento-Borbe et al. 2006). The $\mathrm{pH}$ was determined by $1: 2.5$ (wt/ vol) soil/water suspension. Moisture $(\%)$, temperature $\left({ }^{\circ} \mathrm{C}\right)$, and texture class were assessed by the methodology of Anderson and Ingram (1993), and organic matter $(\mathrm{OM})$ concentration $\left(\mathrm{C}_{\mathrm{org}}\right)$ was calculated by the Walkley-Black method (Walkley and Black 1934). Phosphorous was estimated by extraction with sodium bicarbonate (Olsen et al. 1954), and calcium and magnesium were detected by atomic absorption spectrometry. Nitrate ions were measured by the Raney-Kjeldahl method and potential acidity $\left(\mathrm{H}^{+} \mathrm{Al}\right)$ was determined by an equation based on the $\mathrm{pH}$ in Shoemaker-McClean-Pratt (SMP) buffer solution (pH SMP). Cation exchange capacity (CEC) is the capacity to retain and release cations $\left(\mathrm{Ca}^{2+}, \mathrm{Mg}^{2+}, \mathrm{K}^{+}\right.$, and $\left.\mathrm{Na}^{+}\right)$and the sodium adsorption ratio (SAR) is the measure of soil sodicity, which is calculated as the ratio of sodium to magnesium and calcium.

Soil eDNA extraction. Environmental DNA (eDNA) was isolated from two of the four rhizosphere soil samples, SS-1 and SS-4, using the QIAGEN DNeasy Power Soil Pro DNA isolation kit. Two PowerBead tubes containing $0.5 \mathrm{~g}$ for each sample were used for the isolation. The eDNA was sent to MR DNA (Shallowater, TX, U.S.A.) for sequencing using the Illumina platform (San Diego, CA, U.S.A.).

Soil-inoculated plant trap experiment. Cowpea plants (603; PI 339603 and CB 46; PI 548784) were grown in plastic pots containing $300 \mathrm{~g}$ of a 2:1 vermiculite/perlite mixture with $5 \mathrm{~g}$ of cowpea 
rhizospheric soil added and then topped with sterilized polyethylene beads to minimize contamination (Lobo et al. 2019; Mukhtar et al. 2017). The controls were composed of $2: 1$ vermiculite/perlite with no soil added and were either $\mathrm{N}$-deficient $(-\mathrm{N})$ or supplemented with $\mathrm{N}(+\mathrm{N})\left(625 \mu \mathrm{l}\right.$ each of $1 \mathrm{M}\left[\mathrm{CaNO}_{3}\right]_{2}$ and $\left.1 \mathrm{M} \mathrm{KNO}_{3}\right)$. Cowpea 603 is a slightly salt-tolerant variety whereas cowpea CB 46 is highly salt tolerant (Helms et al. 1991). The first set of pot experiments was performed with cowpea 603 seed, which were inoculated with four different soil samples under normal soil conditions. In the second and third set of experiments, cowpea 603 and CB 46 seed were inoculated with the four different soil samples and grown under slight salinity stress conditions (approximately $1 \%$ $\mathrm{NaCl}$ ) in the greenhouse at the Plant Growth Center, UCLA. The temperature inside the greenhouse ranged between 21 and $30^{\circ} \mathrm{C}$ during the day and 17 and $22^{\circ} \mathrm{C}$ at night. Inoculated plants were watered with 1/4-strength Hoagland solution without nitrogen whereas control plants were watered with 1/4-strength Hoagland solution with or without nitrogen or with sterile water. Three pots with 6 plants/pot were prepared for the control, and six pots of 6 plants each for the treated plants. All plants were harvested after 8 weeks, and data for plant growth parameters such as biomass, shoot length, and nodule number per plant were recorded. Data were statistically analyzed using the Statistical Package for the Social Sciences (SPSS) software (IBM Statistics 23.0). The differences among various treatment means were compared based on the least significant differences at $5 \%(P \leq 0.05)$ probability level by using Duncan's test (Duncan 1955).

Isolation of bacteria from root nodules of cowpea for cultivation-dependent and cultivation-independent analyses. Root nodules were surface sterilized with $10 \%$ bleach for $5 \mathrm{~min}$, washed with sterile water 10 times, then squashed in $50 \mu \mathrm{l}$ of sterile water with a sterile glass rod. The nodule squashate was serially diluted from $10^{-1}$ to $10^{-5}$. Approximately $50 \mu \mathrm{l}$ of dilutions ranging from $10^{-3}$ to $10^{-5}$ were spread onto three different culture media: tryptone yeast extract (TY) agar, tryptone soya agar (TSA), and arginine glycerol (AG) agar. The plates were incubated at $30^{\circ} \mathrm{C}$, usually for 2 to 3 days. However, the actinomycetes (CPN8 and CPN9) were visible only after 6 to 7 or more days of growth on plates. Bacterial colonies were counted and number of bacteria per gram of sample was calculated. The bacterial isolates were repeatedly subcultured to obtain single colonies, which were grown in TY, TSA, and AG broth and stored in $33 \%$ glycerol at $-80^{\circ} \mathrm{C}$ for subsequent characterization.

For the cultivation-independent analysis, surface-sterilized nodules from plants grown in the different saline soils were crushed as described above, and eDNA was extracted from the crushed nodules using the QIAGEN PowerSoil DNA Isolation Kit. The eDNA was stored at $-20^{\circ} \mathrm{C}$ and sent to the Joint Genome Institute for paired-end sequencing using the KAPA-Illumina library creation kit (KAPA Biosystems) and the HiSeq-2500 Illumina platform. A data cleaning process was applied to all sequences prior to analysis. Low-quality bases with a Phred quality value $<20$ were trimmed off the read ends. To determine the taxonomic composition of the microbiome, the $16 \mathrm{~S}$ ribosomal RNA (rRNA) sequences were extracted from the metagenomic shotgun sequencing data using a mapping-based method similar to that described by Shi et al. (2015). The sequences were aligned with paired reads against the rRNA database (Greengenes v13.5, nonredundant precalculated operational taxonomic unit references, 97_otus from PICRUSt) (DeSantis et al. 2006; Langille et al. 2013). The alignments were performed using Bowtie2 (Langmead et al. 2009) to identify sequences, with the best hits having $\geq 80 \%$ nucleotide identity to the references. The annotation of the extracted 16S rRNA sequences was refined by cross-referencing the NCBI Reference Sequence
(Pruitt et al. 2005). The microbial relative abundances in each sample were calculated on the basis of the $16 \mathrm{~S}$ rRNA sequences of the classified taxa.

Morphological and physiological characterization of bacterial isolates. Bacterial colonies were characterized on the basis of color, shape, size, margin, and elevation. The cell shape and motility of bacterial strains were observed by light microscopy. Bacterial isolates were grown in the presence of different salt concentrations $(0$ to $5 \% \mathrm{NaCl})$ at $\mathrm{pH}$ ranges of 6 to 10 and temperatures of 4 to $42^{\circ} \mathrm{C}$.

Amplification, purification, and sequencing of the 16S rRNA gene. Bacteria were suspended from a single colony of the selected isolates grown on TY plates into $20 \mu$ of sterile-filtered water. The 16S rRNA gene was amplified by PCR using the forward primer fD1 and the reverse primer rP1 (Weisburg et al. 1991). Amplification was performed in a total volume of $20 \mu \mathrm{l}$ containing $15 \mu \mathrm{l}$ of sterile-filtered water, $2 \mu 1$ of bacterial sample, $2 \mu 1$ of $10 \times$ Taq buffer $\left(\mathrm{MgCl}_{2}\right), 0.2 \mu \mathrm{l}$ of fD1 and $\mathrm{rD} 1(3.2 \mathrm{pmol} / \mu \mathrm{l}), 0.2 \mu \mathrm{l}$ of dNTPs, and $0.2 \mu \mathrm{l}$ of Taq DNA polymerase. Amplified $16 \mathrm{~S}$ rDNA products in a $0.8 \%$ low-melting-point agarose gel $(100 \mathrm{~V}, 400 \mathrm{~mA}, 1 \mathrm{~h})$ were visualized with ethidium bromide and purified. The gel extraction was performed with the Invitrogen Quick Gel Extraction Kit according to the manufacturer's directions. Purified PCR products were commercially sequenced by using forward and reverse primers (Laragen, U.S.A.).

Phylogenetic analysis. Acquired sequences were assembled and analyzed with the help of Chromus Lite 2.01 sequence analysis software (Technelysium Pty Ltd., Australia). The gene sequences were compared with those deposited in the GenBank nucleotide database using NCBI BLAST. Sequences were aligned using Clustal $\times 2.1$ and a phylogenetic tree was constructed using the neighbor-joining method (Saitou and Nei 1987). Bootstrap confidence analysis was performed on 1,000 replicates to determine the reliability of the distance tree topologies obtained. The evolutionary distances were computed using the maximum composite likelihood method (Tamura et al. 2004) and are presented in the units of number of base substitutions per site. All positions containing gaps and missing data were eliminated from the dataset (complete deletion option). Phylogenetic analyses were conducted in MEGA7 (Kumar et al. 2016).

Assays for plant growth promotion. Phosphate solubilization assay. Pikovskaya phosphate medium was made according to Pikovskaya (1948). For inoculation onto plates, the bacterial strains were grown in liquid medium until stationary phase, at which time the cells were harvested by centrifugation $(8,000 \times g, 10 \mathrm{~min})$ and the pellets washed with sterile water three times to remove any traces of the medium. The cell pellets were diluted to an optical density at $600 \mathrm{~nm}=0.2$ in sterile water. Droplets $(10 \mu \mathrm{l} \mathrm{each})$ were spotted onto the plates and allowed to dry right-side up for $20 \mathrm{~min}$. The plates were incubated upside down at $30^{\circ} \mathrm{C}$ for 3 days and the size of the clearing zone around the colony was measured.

A quantitative analysis of $\mathrm{P}$ solubilization of bacterial isolates was done by the molybdate blue color method (Watanabe and Olsen 1965). Available P was calculated after 7 and 14 days. Cell-free supernatants were used for the quantification of $\mathrm{P}$ solubilization. After recording the $\mathrm{pH}$ of the cell-free supernatants, they were filtered through 0.2- $\mu \mathrm{m}$ sterile filters (Orange Scientific GyroDisc CA-PC, Belgium) to remove any residues. Solubilized phosphates (primary and secondary orthophosphate) were measured by spectrophotometry (Camspec M350-Double Beam UV-Visible Spectrophotometer, U.K.) at $882 \mathrm{~nm}$, and values were calculated using a standard curve $\left(\mathrm{KH}_{2} \mathrm{PO}_{4}\right.$ solutions at 2, 4, 6, 8, 10, and $\left.12 \mathrm{ppm}\right)$.

Siderophore assay. Chrome Azurol S (CAS) agar medium devoid of nutrients was used as an indicator of siderophore 
presence. The components needed for a liter of the overlay medium were as described by Pérez-Miranda et al. (2007). Ten milliliters of a $0.9 \%$ CAS agar gel was spread as an overlay on culture plates of selected strains grown for 4 days on two solid media (Luria-Bertani [LB] and TY). After a maximum period of $15 \mathrm{~min}$, a color change in the blue medium was observed around the colonies. The experiment was repeated three times.

Hydrogen cyanide production assay. Hydrogen cyanide $(\mathrm{HCN})$ detection was done using filter papers (soaked in $0.5 \%$ picric acid in $2 \%$ sodium carbonate), which were placed on the lid of the Petri plate (Sadasivam and Manickam 1992).

Antifungal activity assay. The antifungal activity of the bacterial isolates was observed using a coculture method with fungal pathogens (Khan et al. 2018). A plug from the respective fungal culture was cut and placed in the center of a potato dextrose agar plate (Sigma-Aldrich, St. Louis, MO, U.S.A.). The plate was sealed with Parafilm and labeled as the control. Another plug from fungal culture was placed in the center of a new plate. Using a sterile inoculating loop, a single bacterial colony was transferred onto the plate by streaking it $2 \mathrm{~cm}$ away from the fungus on four sides. The plates were sealed with Parafilm and placed in an incubator at $30^{\circ} \mathrm{C}$ for 7 days. Inhibition of fungal mycelial growth near the bacterial growth indicated antifungal activity. The fungal strains used to evaluate antifungal activity of the bacterial isolates were Fusarium oxysporum, F. solani, Alternaria solani, Aspergillus flavus, and Curvularia sp.

Enzyme assays for bacterial isolates. Protease activity was tested on the medium described by Kumar et al. (2009). Amylase activity was identified by using a starch hydrolysis test (Sigmon 2008). Cellulase activity was tested by using LB and TY media containing $1 \%$ carboxy methyl cellulose, and indicated by formation of a clear zone after staining with Gram's iodine for 3 to 5 min (Kasana et al. 2008). Lipase activity was examined by using LB and TY media with $1 \%$ butyrin and Tween 80 in a hydrolysis assay, as described by Sierra (1957). Chitinase activity was detected with colloidal chitin medium, as described by Saima and Roohi (2013). Clear zones around the bacterial colonies are considered positive results for chitinase (Kaur et al. 2012).

\section{RESULTS}

Physicochemical properties of cowpea-planted rhizosphere soil samples collected in Mandi Bahauddin. Soil physicochemical properties such as electrical conductivity (EC1:1 [dS/m]), soil $\mathrm{pH}, \mathrm{OM}$, texture class, CEC, and SAR all affect the rhizosphereassociated microbial communities. The four soil samples were characterized by a great spatial variability and covered a significant variation in different soil physicochemical properties. Soil samples SS-2 and SS-4 were more saline (EC1:1 values 5.15 and 5.35, respectively) as compared with SS-1 and SS-3 (4.85 and 4.56, respectively). However, SS-2 and SS-4 were found to have more OM (31.75 and $39.69 \mathrm{~g} / \mathrm{kg}$, respectively) than SS-1 and SS-3, which were also more alkaline (pH 7.89 and 8.11, respectively) than SS-2 and SS-4 soils (Supplementary Table S1). For soil temperature, the highest value at the time of sampling was detected in SS-1 $\left(39.24^{\circ} \mathrm{C}\right)$, whereas the other soils were slightly cooler (Supplementary Table S1). The highest moisture content (24\%) was measured in SS-3 and the lowest (17\%) in SS-2; SS-1 and SS-4 had similar values (Supplementary Table S1). Available P, K, Ca, and $\mathrm{Mg}$ contents were similar for all four soils, except $\mathrm{P}$ in SS-3, and SAR values were similar for all except SS-2, where it was higher (Supplementary Table S1). Overall, of all the samples included in the study, based on temperature, $\mathrm{pH}, \mathrm{OM}, \mathrm{SAR}$, and CEC values, we hypothesized that the SS- 2 followed by SS- 4 might provide a better environment for microbial functional competition and plant growth promotion in comparison with the SS-1 and SS-3 collections. We proceeded to test this hypothesis.

Results of trap experiments. Trap experiments with cowpea were pursued because we hypothesized that this important crop legume would form root nodules that contained not only nitrogenfixing bacteria, but also "helper" bacteria that promoted cowpea growth in these soils based on previous studies (Martínez-Hidalgo and Hirsch 2017). Plant-growth-promoting responses such as changes in shoot length, plant biomass, and number of nodules per plant were recorded for control cowpea and for cowpea plants grown in pots under different salt stress conditions. The largest increase in shoot length occurred in cowpea 603 plants inoculated with SS-4 (Fig. 1; Supplementary Fig. S2). SS-1- and SS-3inoculated plants had shoot lengths similar to those of the $-\mathrm{N}$ no-soil controls whereas both SS-2- and SS-4-grown plants exhibited shoot lengths and plant biomass equivalent to the $+\mathrm{N}$ soilless control. Also, shoot length and plant biomass increased slightly more in control soil-inoculated cowpea 603 plants than in cowpea 603 and CB 46 plants grown under salinity stress (Fig. 1A and B). SS-2- and SS-4-grown plants also developed more nodules per plant compared with cowpea plants inoculated with SS-1 and SS-3 (Fig. 1C). Cowpea 603 plants grown in $+\mathrm{N}$ medium without salt were green and healthy whereas, when they were grown in SS-1 and SS-3, the 603 plants were yellow and showed limited root development. The salt-tolerant CB 46 cowpea was less affected by the SS- 1 and SS-3 soils than cowpea 603 and, in SS-2 and SS-4 soils, both cultivars were more similar in appearance to the no-salt control even when grown under salt stress (Supplementary Fig. S2).

The relative increase in plant biomass varied between 31 and $61 \%$ in treated cowpea 603 plants grown under normal soil conditions over the control (without soil inoculum). Treated cowpea 603 and CB 46 plants grown under salinity stress showed a 30 to 40 and 29 to $63 \%$ increase in plant biomass, respectively (Fig. 1; middle row). In addition, cowpea 603 and CB 46 plants inoculated with SS-2 and SS-4 soils produced more (or slightly more) nodules per plant in comparison with plants inoculated with SS-1- and SS-3 under normal as well as salinity-stress conditions. Although salinity stress did have an inhibiting effect on nodule number, some of its effect was mitigated by the CB 46 genotype (Fig. 1; bottom row).

In summary, plants inoculated with SS-2 and SS-4 showed overall better growth compared with plants inoculated with SS-1 and SS-3 under both normal and salinity stress conditions. The differences in $\mathrm{pH}, \mathrm{OM}$, and CDC values between SS-1 and SS-3 soils versus SS-2 and SS-4 soils may explain the different growth effects of the cowpea cultivars; however, more studies are needed.

eDNA analysis of SS-1 and SS-4. We chose two of the four rhizosphere soils tested above for eDNA analysis. SS-1 was an example of a soil that, when added to the trap plant pot, did not increase plant growth much over the $-\mathrm{N}$ control; it was more sodic and siltier than the other soils. In contrast, SS-4, which resulted in growth stimulation very similar to the $+\mathrm{N}$ control (Fig. 1), had the highest electrical conductivity, and the $\mathrm{pH}$ was closer to neutral than the other three soils.

A comparison of the microbial diversity at the phylum level from SS-1 and SS-4 soils shows the overall pattern of bacterial sequences in the two samples (Fig. 2). Both soils are dominated by Actinobacteria, Firmicutes, and Proteobacteria eDNA sequences. The relative abundance of actinobacterial sequences was not much different between the two soil types (28.0 versus $27.4 \%$; SS-1 versus SS-4, respectively) but it differed for the Firmicutes (28.5 versus 26.4\%) and slightly for the Proteobacteria (23.6 versus 24.9\%). The values for Acidobacteria and Chloroflexi also varied depending on the soil sample (Supplementary Table S2). The 
general trend for the less-represented phyla was a reduction in DNA sequence abundance of certain phyla in SS-4, except for Nitrospirae, which increased. Overall, there was no significant difference in the abundance of Actinobacteria, Firmicutes, and Proteobacteria spp. but significant variations were observed in the abundance of less-represented phyla between two soil samples (Supplementary Table S2).

Nodule microbiome analysis. Investigations of metaprofiling of nodules of plants grown in the four different soils (soil nodule samples were designated sn1 to sn4) at the genus level showed that
A

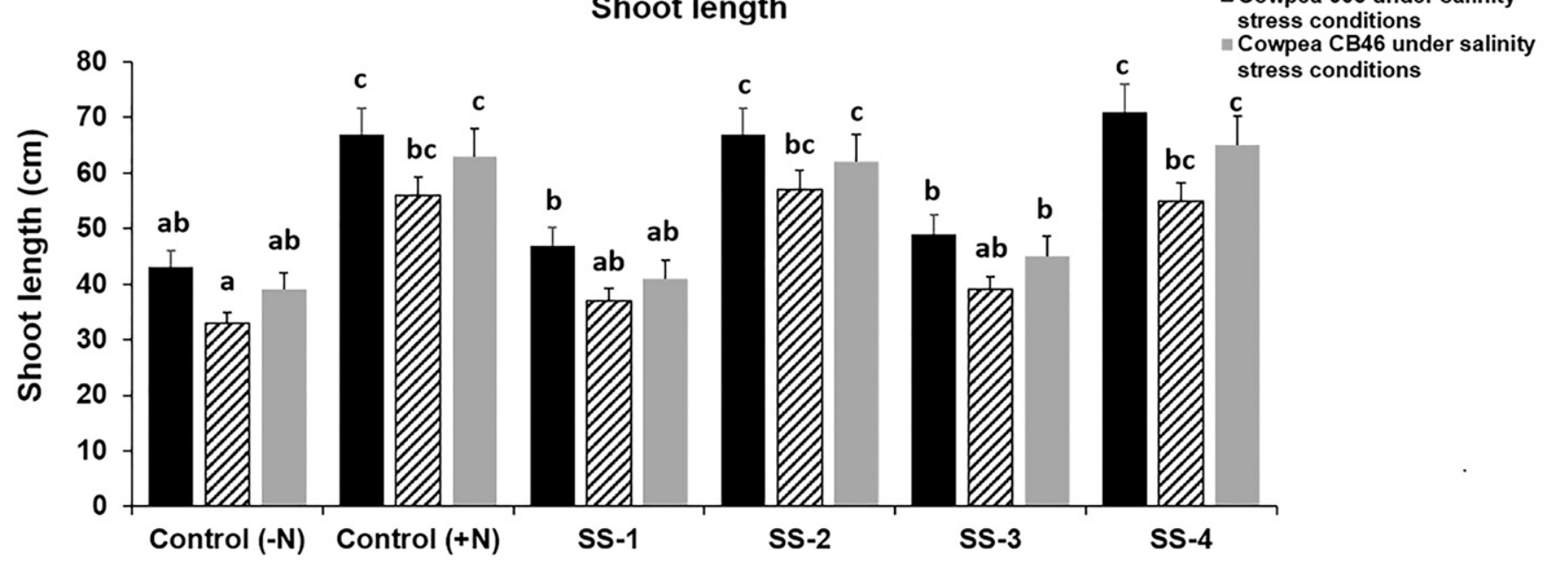

B

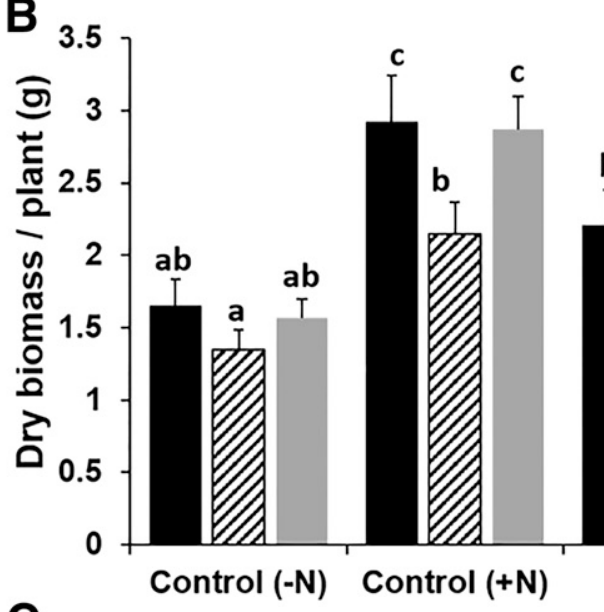

C

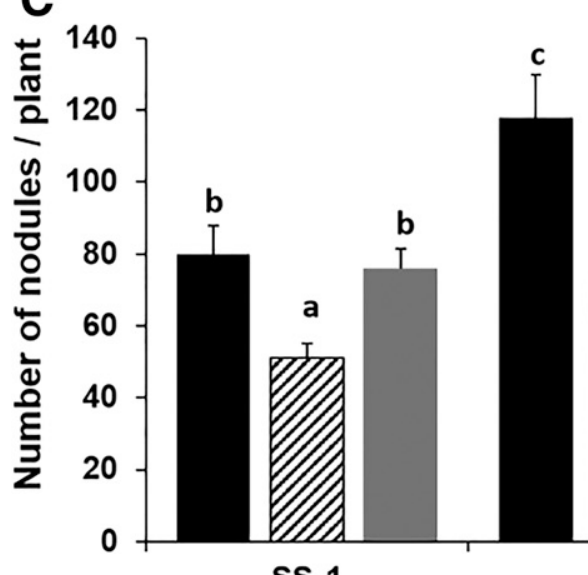

SS-1

Plant biomass

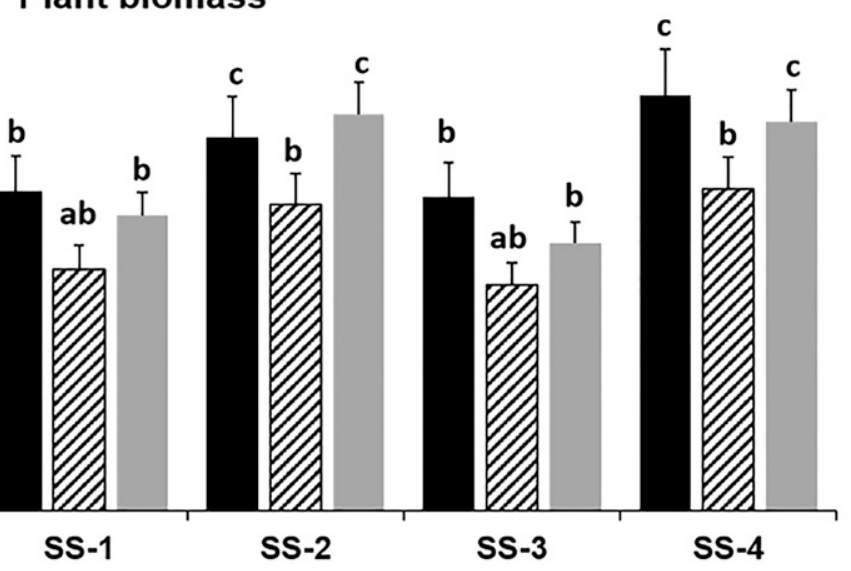

Root Nodules

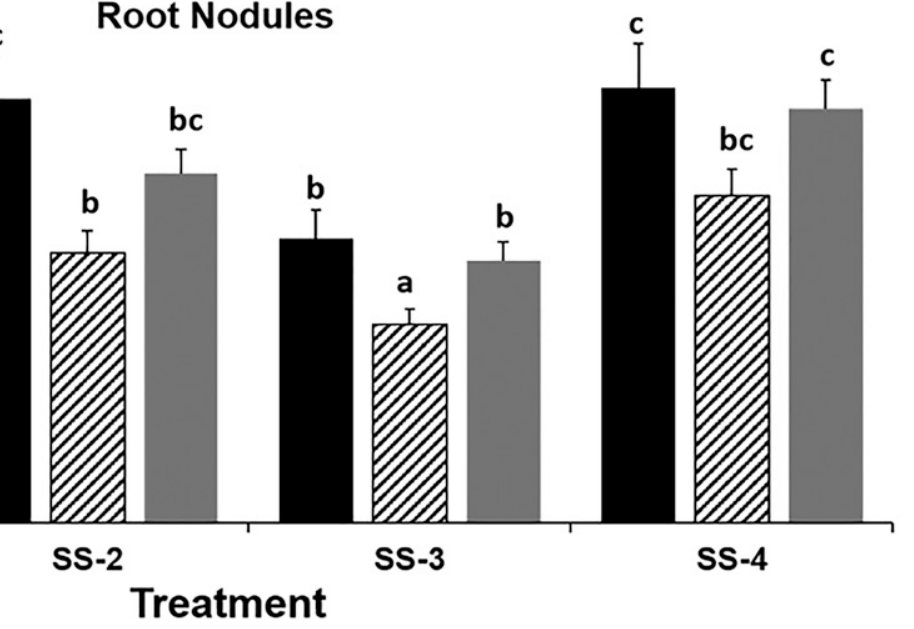

Fig. 1. Effect of inoculation with different soil samples (SS) collected from semiarid region of Pakistan on plant growth: A, shoot length; B, plant biomass; and $\mathbf{C}$, number of nodules of cowpea varieties 603 and $\mathrm{CB} 46$. Symbols: $-\mathrm{N}=\mathrm{N}$-deficient medium and $+\mathrm{N}=$ medium supplemented with $\mathrm{N}$. Differences among various treatment means were compared on the basis of the least significant differences at $5 \%(P \leq 0.05)$ probability level by using Duncan's test. Letters on graph bars represent statistically different values at the $5 \%$ level. 
the dominant bacterial species in all the cowpea nodule microbiomes was the $\alpha$-proteobacterial genus Bradyrhizobium, based on relative abundance (Fig. 3; Supplementary Table S3). We could not determine with certainty the identity of the strain beyond the genus level but several different Bradyrhizobium species are known to nodulate cowpea in Africa (Pule-Meulenberg et al. 2010; Steenkamp et al. 2008). Detected in much lower percentages were DNA signatures of other bradyrhizobia, including the genera Bosea, Afipia, Rhodopseudomonas, and Oligotropha. Thus, the relative abundances of Bradyrhizobiaceae species within the sn1 to sn4 microbiomes were 92.3, 84.7, 91.5, and 94.3\%, respectively. By contrast, genera of families Rhizobiaceae (Ensifer, Rhizobium/ Agrobacterium, and Shinella) combined with Hyphomicrobieaceae (Rhodoplanes) and Phyllobacteriaceae (Mesorhizobium) were found at much lower abundances $(\mathrm{sn} 1=0.7 \%, \mathrm{sn} 2=8.3 \%, \mathrm{sn} 3=$ $2.1 \%$, and $\operatorname{sn} 4=0.3 \%$ ) in the four nodule microbiomes. Other Proteobacteria found within nodules, albeit at very low abundance, included the genera Acidophilium ( $\alpha$-Proteobacteria, Acetobacteraceae) and Pseudomonas ( $\gamma$-Proteobacteria, Pseudomonaceae) (Supplementary Table S3). The "other Proteobacteria" category exhibited a relative abundance of 3.2, 3.8, 3.4, and $2.8 \%$ for sn1 to sn 4 microbiomes, respectively. Finally, the grouping designated "nonProteobacteria (others)" accounts for an average of $0.1 \%$ in relative abundance for sn 1 to sn 3 and $0 \%$ for sn 4 . These values are so low as to be undetectable in the bar graph (Fig. 3). Interestingly, the nodule microbiomes sn 1 and sn 3 are very similar to each other whereas sn2 and sn4 differ from them as well as from each other due to a greater percentage of Rhizobiaceae species detected in $\mathrm{sn} 2$.

Isolation and characterization of nodule bacterial isolates and their identification. In total, 51 bacterial isolates were isolated from cowpea nodules of plants grown in the four different soil samples (Supplementary Table S4). Most of the isolates grew well at $\mathrm{pH} 6$ to 8 , on 1 to $3 \% \mathrm{NaCl}$, and at 28 to $37^{\circ} \mathrm{C}$; however, only 35 to $40 \%$ of the bacterial isolates (Bacillus and some Pseudomonas strains) grew at 4 or $42^{\circ} \mathrm{C}$ (data not shown).

Following a thorough morphological and physiological characterization, 34 nodule isolates were selected and identified by $16 \mathrm{~S}$ rRNA gene analysis to the closest related species. According to the sequence match results, the bacterial strains identified from root nodules of cowpea mainly belonged to bacterial genera often shown

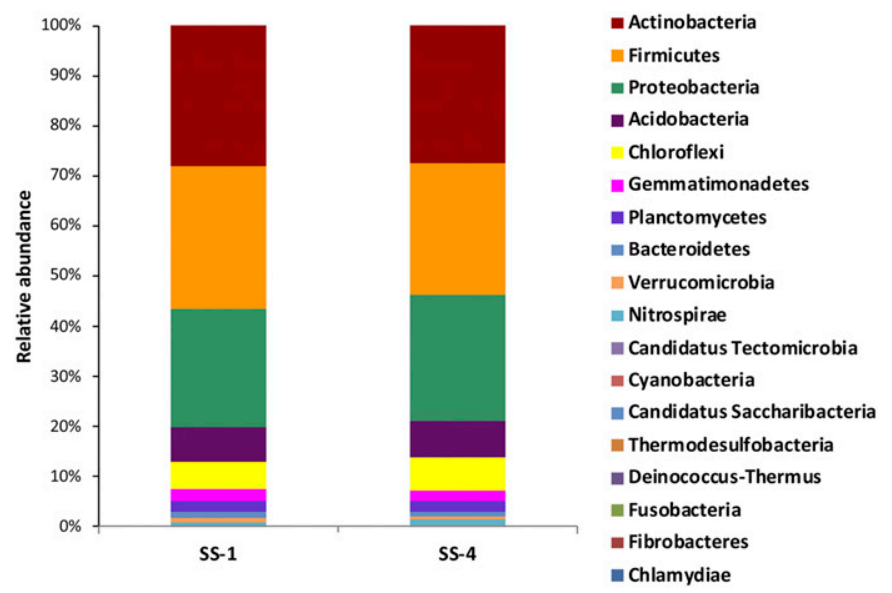

Fig. 2. Relative abundance of environmental DNA sequences at the phylum level from two different soils: SS-1, which did not stimulate cowpea growth over the $\mathrm{N}$-deficient $(-\mathrm{N})$ control, versus SS-4, which promoted growth to a level equivalent to the $\mathrm{N}$-supplemented $(+\mathrm{N})$ control. Both soils were isolated from the Mandi Bahauddin region of Pakistan. to be plant-growth-promoting rhizobacteria (PGPR); namely, Mesorhizobium, Sinorhizobium, Bradyrhizobium, Paenibacillus, Bacillus, Pseudomonas, and others (Table 1). Among the PGPR were the actinomycetes Frankia sp. DSM 45818 (CPN9), Streptomyces galilaeus (CPN7), and S. griseoaurantiacus (CPN8), which were isolated from nodules. Several isolates were identified as pathogens or nosocomial pathogens, including Klebsiella aerogenes (CPN11 and CPN20) (formerly Enterobacter) (Tindal et al. 2017), Aeromonas veronii (CPN19) (Janda and Abbott 2010), Pseudomonas monteilli (CPN44) (Elomari et al. 1997, and Enterobacter cloacae (CPN48) (Sanders and Sanders 1997) (Table 1).

Plant-growth-promoting abilities of bacterial strains. Isolated bacterial strains were tested for plant-growth-promoting traits such as nitrogen fixation, phosphate solubilization, and siderophore and HCN production. Of the 34 isolates, 19 strains were able to solubilize phosphate, with the maximum activity $(142.23 \mu \mathrm{g} / \mathrm{ml})$ exhibited by strain CPN35. In all, 8 strains were positive for siderophore production and 12 strains were positive for $\mathrm{HCN}$ production (data not shown).

Antifungal activity of bacterial strains. The 34 RNA-sequenceidentified bacterial isolates were tested for antifungal activity against five fungal pathogens: F. oxysporum, F. solani, Curvularia sp., Alternaria solani, and Aspergillus flavus. The details of which bacterial strains are effective against the various fungi are shown in Supplementary Table S5.

Extracellular enzymes production by bacterial isolates as mechanisms of fungal growth inhibition. The ability of bacterial strains to produce extracellular enzymes such as cellulase, lipase, chitinase, amylase, and protease was assessed. The strains varied in their ability to produce these enzymes (Supplementary Table S6).

\section{DISCUSSION}

Because arid countries such as Pakistan, which have highly saline soils, are often the first to respond to increasing temperatures brought about by a changing climate, we pursued an investigation of the effect of salinity and other parameters on the soil microbial communities that make up the cowpea rhizosphere and nodule microbiome with the goal of understanding the potential of their bacteria for being used as

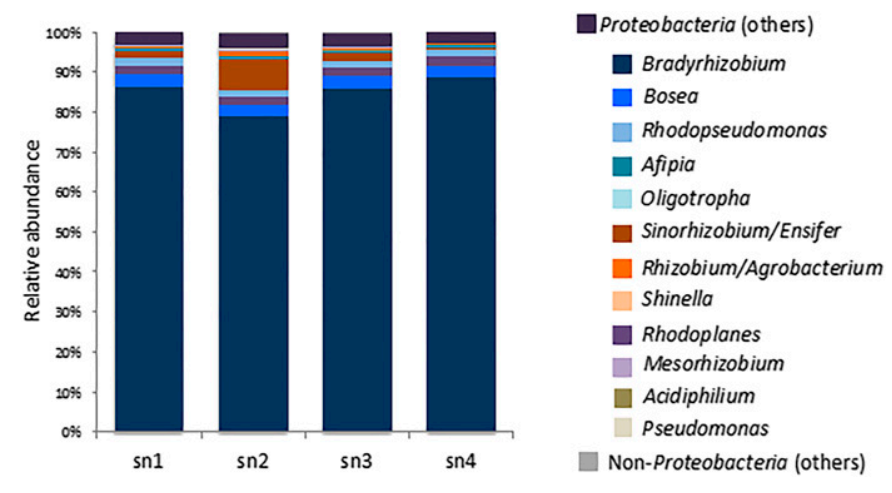

Fig. 3. Relative abundance of microbial sequences at the genus level from DNA of cowpea nodules collected from four different soils (sn1 to sn4) from the Mandi Bahauddin region of Pakistan. In all cases, Bradyrhizobia was the dominant genus but other proteobacterial species, some of them distinct from rhizobia such as Acidiphilium and Pseudomonas, were also detected. Nonproteobacterial species, however, were barely detectable in the nodule microbiome in spite of their abundance as nodule isolates. 
inoculants. Trap experiments were performed using two cowpea varieties, the salt-sensitive variety 603 and salt-tolerant variety $C B$ 46. Both were inoculated with soil samples from four different sites in the Mandi Bahauddin area of Punjab, Pakistan. Increases in salinity cause changes in soil properties such as OM, leaching and erosion, loss of nutrients, and changes in both quantity and composition of soil microbial communities (Canfora et al. 2014; Mukhtar et al. 2018).

Cowpea 603 and CB46 plants showed a significant increase in plant growth when inoculated with SS-2 and SS-4, even under salinity stress (10 to 49 and 20 to $52 \%$ in plant biomass, respectively) posttreatment, compared with uninoculated control plants. Previous studies have shown that the soil type has a significant influence on the microbial populations of legume nodules and, ultimately, plant growth (Berg and Smalla 2009; Leite et al. 2017).
Through an analysis of the nodule microbiomes of plants grown in the different soils, we found that members of the Bradyrhizobiaceae family dominated the microbiome (78.99 to $88.8 \%$ for the four microbiomes) but species of Rhizobiaceae and other proteobacteria were also detected, although at significantly lower levels. However, Salter et al. (2014) called into question whether or not the microbiome constituents in a low-biomass sample were members of the community and not contaminants because numerous microbes had been detected even in blank controls. For example, Bosnea and Afipia (Bradyrhizobiaceae) were suggested to be common contaminating genera (Salter et al. 2014). Because the two genera were part of the uncultivated group isolated from nodule squashes, the possibility exists that either one or both of these members of the family Bradyrhizobiaceae might be contaminants because their abundance values in the nodule are very low in the four different nodule samples (Bosnea, average $=3.3 \%$ and Afipia, average $=1.8 \%$ ).

TABLE 1

Identification of bacterial isolates from cowpea nodules (CPN) based on 16S ribosomal RNA gene sequence analysis

\begin{tabular}{|c|c|c|c|c|}
\hline Isolate code & Organism identified & Accession number & Closest type strain in $\mathrm{NCBI}$ database & Sequence similarity (\%) \\
\hline CPN1 & Mesorhizobium & MH491055 & Mesorhizobium ciceri ATCC 700744 (KX226354) & 99.45 \\
\hline CPN2 & Ensifer & MH491056 & Ensifer aridi DSM 11282 (KR780016) & 100 \\
\hline CPN4 & Paenibacillus & MH491058 & Paenibacillus ginsengagri DSM 19942 (AB245383) & 99.63 \\
\hline CPN5 & Paenibacillus & MH491059 & Paenibacillus zanthoxyli JH29 (DQ358724) & 100 \\
\hline CPN8 & Streptomyces & MH491062 & Streptomyces griseoaurantiacus NBRC 13381 (HQ850417) & 99.45 \\
\hline CPN9 & Frankia & MH491063 & Frankia sp. DSM 45818 (AF063640) & 98.55 \\
\hline CPN10 & Bradyrhizobium & MH491064 & Bradyrhizobium japonicum DES 122 (AF234888) & 100 \\
\hline CPN11 & Klebsiella & MH491065 & Klebsiella aerogenes CCRC 10370 (KT998837) & 99.23 \\
\hline CPN15 & Bacillus & MH491069 & Bacillus pumilus NRS 272 (KX767153) & 99.25 \\
\hline CPN16 & Pseudomonas & MH491070 & Pseudomonas putida DSM 291 (HF584918) & 99.64 \\
\hline CPN17 & Pseudomonas & MH491071 & Pseudomonas fluorescens ATCC 13525 (MH191400) & 98.44 \\
\hline CPN18 & Pseudomonas & MH491072 & Pseudomonas putida NCTC 10936 (KC952984) & 99.85 \\
\hline CPN19 & Aeromonas & MH491073 & Aeromonas veronii ATCC 35624 (MG063196) & 100 \\
\hline CPN20 & Klebsiella & MH491074 & Klebsiella aerogenes CCRC 10370 (GU459208) & 99.10 \\
\hline CPN21 & Bradyrhizobium & MH603868 & Bradyrhizobium japonicum DSM 30131 (AF234888) & 99.21 \\
\hline CPN22 & Bacillus & MH817487 & Bacillus safensis LMG 26769 (MH177247) & 99.07 \\
\hline CPN27 & Mesorhizobium & MH817488 & Mesorhizobium ciceri ATCC 700744 (KX226354) & 99.34 \\
\hline CPN43 & Mesorhizobium & MH603874 & Mesorhizobium olivaresii LMG 29295 (FM203301) & 99.21 \\
\hline CPN44 & Pseudomonas & MH603875 & Pseudomonas monteilii DSM 11388 (KJ819574) & 99.48 \\
\hline CPN45 & Mesorhizobium & MH603876 & Mesorhizobium alhagi HAMBI 3019 (KY753240) & 99.36 \\
\hline CPN47 & Bacillus & MH603877 & Bacillus megaterium ATCC 14581 (HM771671) & 99.18 \\
\hline CPN48 & Enterobacter & MH603878 & Enterobacter cloacae DSM 16690 (GU459208) & 99.27 \\
\hline
\end{tabular}


However, many Bradyrhizobiaceae species require long incubation times before colonies become apparent on plants and, in most cases, the cowpea nodule isolate incubations did not exceed 1 week. For many of the slow-growing genera of Bradyrhizobiaceae (Bosnea, Rhodopseudonomas, Afipia, and others), longer time periods (at least 2 weeks) are often needed for growth after isolation from nodules and transfer to culture medium. Further supporting our data are a phylogenetic analysis (Fig. 4) of the root nodule bacterial isolates of cowpea 603 and CB46 plants inoculated with the saline soil samples. Numerous nodule isolates were found to be members of either the Rhizobiaceae or Bradyrhizobiaceae family, strongly suggesting that these genera are not contaminants.

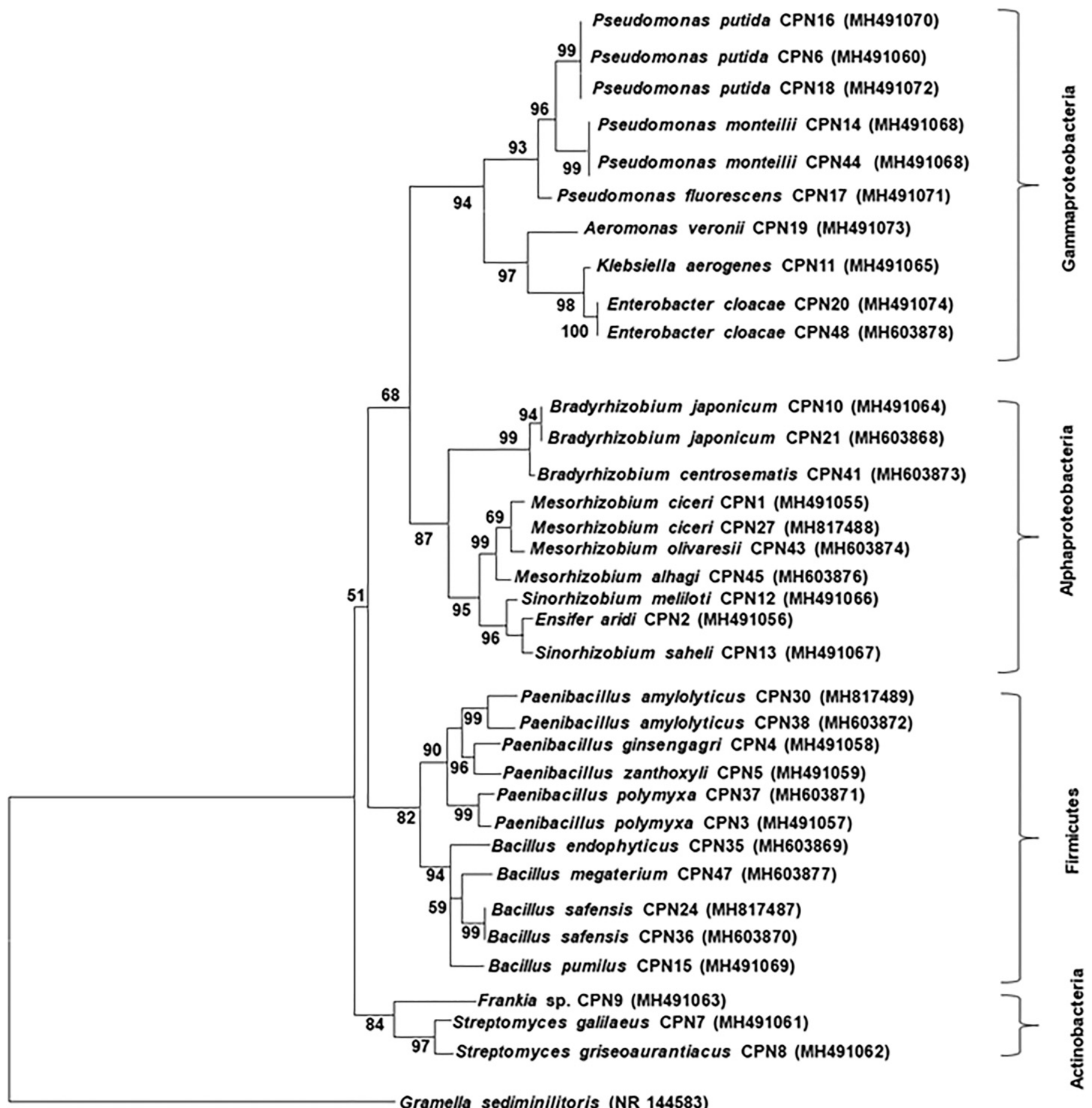

0.10

Fig. 4. Neighbor-joining tree based on $16 \mathrm{~S}$ ribosomal RNA gene sequences of bacterial strains isolated from cowpea nodules. Percentage of replicate trees in which the associated taxa clustered together in the bootstrap test (1,000 replicates) is shown next to the branches. Evolutionary distances were computed using the maximum composite likelihood method and are in the units of number of base substitutions per site. 
We do not know the reasons for the difference in relative abundance between the rhizobial data obtained from the microbiome analyses and the isolation methodology. Studies have shown that soil physicochemical properties or physiological changes within the nodule itself may affect the survivability or distribution of indigenous rhizobia isolated from cowpea nodules (Damaris et al. 2017; Leite et al. 2017; Pule-Meulenberg et al. 2010). Also, media composition, growth conditions, as well as incubation time and temperature all play a role, as well as variations in the methods of microbiome analysis. An additional variable may be that the plant selects bacteria at either the rhizoplane (Wattenburger et al. 2019) or, in the case of a legume, the root hair level. Changes in root exudation profiles may also have an influence.

With regard to the firmicutes, the bacterial isolates investigated in this study were mostly identified as Paenibacillus and Bacillus based on isolation of bacteria from nodules (Fig. 4). Nodule isolates from cowpea plants grown in semiarid areas of Brazil were also frequently identified as Firmicutes (Bacillus and Paenibacillus) (Costa et al. 2013), and many studies have reported that the majority of isolates from cowpea nodules belong to the phyla Firmicutes, Proteobacteria, and Actinobacteria (Jaramillo et al. 2013; Leite et al. 2017). However, the metaprofiling of the nodule microbiome in our study demonstrated that DNA from Firmicutes and Actinobacteria was not detected in cowpea nodules; only the DNA of Proteobacteria. This result may be related to the type of DNA isolation kit used, sample source or treatment (Mackenzie et al. 2015), or as-yet-unknown reasons. Nevertheless, both Firmicutes and Actinobacteria species were isolated from surface-sterilized nodules, and our results and those of others demonstrate that these two groups are well represented among the nodule isolates. For example, both the genera Streptomyces and Frankia (Supplementary Table S1) were isolated from cowpea nodules in this study and in other nodule studies (Leite et al. 2017; Tani et al. 2003) but were not detected in the nodule microbiome analysis.

An exceptionally low relative abundance level of Pseudomonas sequences was also detected in the nodule microbiome, but species of $\gamma$-Proteobacteria (Pseudomonas) and (Enterobacter/Klebsiella) were consistently isolated and characterized from cowpea nodules collected from plants grown under salt stress conditions (Fig. 4).

In reference to the rhizosphere, an analysis of the SS-1/SS-4 and SS-2/SS-4 rhizosphere soils demonstrated that the former was more saline and drier than the latter. These features as well as some of the differences in physicochemical characteristics (e.g., CEC values, $\mathrm{pH}$, and amount of $\mathrm{OM}$ ) may explain the lack of robust plant growth in several of the soil samples.

Summary. Numerous bacteria were detected and isolated from trap plant cowpea nodules. Some may promote plant growth directly by nitrogen fixation and mineral solubilization, or indirectly by production of antibacterial and antifungal compounds (Goswami et al. 2016; Gupta et al. 2015; Malik et al. 1997). Many of the isolates obtained in this study were positive for more than two PGPR traits. In all, $>90 \%$ of the strains exhibited nitrogen fixation ability and $>55 \%$ of bacterial isolates from cowpea nodules exhibited phosphate-solubilizing ability. Finally, the majority of the Pseudomonas, Bacillus, and Enterobacter strains isolated from cowpea nodules were positive for siderophore and $\mathrm{HCN}$ production. Our study also showed that isolates belonging to the genera Pseudomonas, Paenibacillus, and Bacillus inhibit the proliferation of three different fungal pathogens: F. oxysporum, F. solani, and Curvularia sp. Both Pseudomonas and Bacillus spp. have been reported as growth inhibitors for different fungal pathogens and provide protection against a number of plant diseases (Ali et al. 2015; Khan et al. 2017; Shahid et al. 2017). More than one-half of the isolated strains, especially members of the genera Paenibacillus,
Bacillus, Pseudomonas, and Enterobacter, exhibited cellulase, chitinase, amylase, and protease activity, and a large number of PGPR strains (Pseudomonas, Enterobacter, Rhizobium, and Bacillus) promote plant growth and suppress plant diseases by producing siderophores, hydrolytic enzymes, and HCN (Chen et al. 2013; Khan et al. 2018; Mehnaz et al. 2010).

This study aimed to assess the effect of native soil microbial communities on the composition of nodule microbiome in cowpea under salinity stress conditions. The results of trap experiments confirmed that cowpea inoculated with two of the soil samples from Mandi Bahauddin in Punjab, Pakistan displayed enhanced growth as compared with the $-\mathrm{N}$ soilless control, and that the growth was very similar to that of the $+\mathrm{N}$ no-soil control. Insight into the bacterial communities of rhizosphere soil and cowpea root nodules, which served as trap plants, was also obtained. Although the eDNA of nodule microbiome consisted of mainly species of Proteobacteria, various other bacteria, including Pseudomonas, Paenibacillus, Bacillus, and several Actinobacteria, were isolated from cowpea nodules inoculated with four different salinity-stressed soils. Some bacterial strains, especially P. fluorescens CPN14, Bacillus endophyticus CPN35, B. pumilus CPN15, and Paenibacillus polymyxa $\mathrm{CPN} 3$, identified from the root nodules, have been characterized as PGPR and have potential for stimulating plant growth and development. Taken together, these bacterial strains have the potential to be useful as biofertilizers and plant growth promoters for crops growing in salinity-affected, arid soils.

\section{ACKNOWLEDGMENTS}

We thank S. Lieberman and other members of the Hirsch lab (UCLA) for their help and support with various experiments and T. Close of the University of California, Riverside for seed of V. unguiculata CB 46.

\section{LITERATURE CITED}

Adviento-Borbe, M. A., Doran, J. W., Drijber, R. A., and Dobermann, A. 2006. Soil electrical conductivity and water content affect nitrous oxide and carbon dioxide emissions in intensively managed soils. J. Environ. Qual. 35: 1999-2010.

Ali, G. S., Norman, D., and El-Sayed, A. S. 2015. Soluble and volatile metabolites of plant growth-promoting rhizobacteria (PGPRs): Role and practical applications in inhibiting pathogens and activating induced systemic resistance (ISR). Adv. Bot. Res. Acad. Press 75:241-284.

Ali, Y., Aslam, Z., Hussain, F., and Shakur, A. 2004. Genotype and environmental interaction in cowpea (Vigna unguiculata L.) for yield and disease resistance. Int. J. Environ. Sci. Technol. 1:119-123.

Anderson, J. M., and Ingram, J. S. 1993. Soil physical analyses. Pages 93-94 in: Tropical Soil Biology and Fertility: A Handbook of Methods, 2nd ed. CAB International, Wallingford, U.K.

Ardley, J. K., Parker, M. A., O’Hara, G. W., Reeve, W. G., Yates R. J., Dilworth, M. J., Willems, A., and Howieson, J. G. 2012. Microvirga lupini sp. nov., Microvirga lotononidis sp. nov. and Microvirga zambiensis sp. nov. are alphaproteobacterial root-nodule bacteria that specifically nodulate and fix nitrogen with geographically and taxonomically separate legume hosts. Int. J. Syst. Evol Microbiol. 62:2579-2588.

Aserse, A. A., Räsänen, L. A., Aseffa, F., Hailemariam, A., and Lindström, K. 2013. Diversity of sporadic symbionts and nonsymbiotic endophytic bacteria isolated from nodules of woody, shrub, and food legumes in Ethiopia. Appl. Microbiol. Biotechnol. 97:10117-10134.

Beijerinck, M. W. 1888. The root-nodule bacteria. Bot. Zeitung. 46:725-804.

Berg, G., and Smalla, K. 2009. Plant species and soil type cooperatively shape the structure and function of microbial communities in the rhizosphere. FEMS Microbiol. Ecol. 68:1-13.

Bontemps, C., Elliott, G. N., Simon, M. F., Dos Reis, F. B., Gross, E., Lawton, R. C., Neto, N. E., de Fátima Loureiro, M., De Faria, S. M., Sprent, J. I., James, E. K., and Young, J. P. 2010. Burkholderia species are ancient symbionts of legumes. Mol. Ecol. 19:44-52. 
Canfora, L., Bacci, G., Pinzari, F., Lo Papa, G., Dazzi, C., and Benedetti, A. 2014. Salinity and bacterial diversity: To what extent does the concentration of salt affect the bacterial community in a saline soil? PLoS One 9:e106662.

Chen, L. H., Lin, C. H., and Chung, K. R. 2013. A nonribosomal peptide synthetase mediates siderophore production and virulence in the citrus fungal pathogen Alternaria alternata. Mol. Plant Pathol. 14:497-505.

Costa, E. M., Nóbrega, R. S. A., Carvalho, F., Trochmann, A., Ferreira, L. V. M., and Moreira, F. M. S. 2013. Promoção do crescimento vegetal e diversidade genética de bactérias isoladas de nódulos de feijão-caupi [Plant growth promotion and genetic diversity of bacteria isolated from cowpea nodules]. Pesqui. Agropecu. Bras. 48:1275-1284.

Damaris, K. O., Nyaboga, E. N., Wagacha, J. M., and Mwaura, F. B. 2017. Morphological and genetic diversity of Rhizobia nodulating cowpea (Vigna unguiculata L.) from agricultural soils of lower eastern Kenya. Int. J. Microbiol. 2017:8684921.

Deng, Z. S., Zhao, L. F., Kang, Z. Y., Yang, W. Q., Lindström, K., Wang, I. T., and Wei, G. H. 2011. Diversity of endophytic bacteria within nodules of the Sphaerophysa salsula in different regions of Loess Plateau in China. FEMS Microbiol. Ecol. 76:463-475.

DeSantis, T. Z., Hugenholtz, P., Larsen, N., Rojas, M., Brodie, E. L., Keller, K., Huber, T., Dalevi, D., Hu, P., and Andersen, G. L. 2006. Greengenes, a chimera-checked 16S rRNA gene database and workbench compatible with ARB. Appl. Environ. Microbiol. 72:5069-5072.

Duncan, D. B. 1955. Multiple range and multiple F tests. Biometrics 11:1-42.

Eberl, L., and Vandamme. P. 2016. Members of the genus Burkholderia: Good and bad guys [version 1; peer review: 3 approved]. F1000Research 2016, 5(F1000 Faculty Rev):1007.

Elomari, M., Coroler, L., Verhille, S., Izard, D., and Leclerc, H. 1997. Pseudomonas monteilii sp. nov., isolated from clinical specimens. Int. J. Syst. Bacteriol. 47:846-852.

Estrada-de los Santos, P., Palmer, M., Chávez-Ramírez, B., Beukes, C., Steenkamp, E. T., Briscoe, L., Khan, N., Maluk, M., Lafos, M., Humm, E., Arabit, M., Crook, M., Gross, E., Simon, M. F., Bueno dos Reis Junior, F., Whitman, W. B., Shapiro, N., Poole, P. S., Hirsch, A. M., Venter, S. N., and James, E. K. 2018. Whole genome analyses suggest that Burkholderia sensu lato contains two further novel genera (Mycetohabitans gen. nov., and Trinickia gen. nov.): Implications for the evolution of diazotrophy and nodulation in the Burkholderiaceae. Genes (Basel) 9:389.

Garg, N., and Geetanjali. 2007. Symbiotic nitrogen fixation in legume nodules: Process and signaling. A review. Agron. Sustain. Dev. 27:59-68.

Goswami, D., Thakker, J. N., and Dhandhukia, P. C. 2016. Portraying mechanics of plant growth promoting rhizobacteria (PGPR): A review. Cogent Food Agric. 2:11275.

Graham, P. H. 2008. Ecology of the root-nodule bacteria of legumes. Pages 23-58 in: Nitrogen-fixing Leguminous Symbioses. Nitrogen Fixation: Origins, Applications, and Research Progress, vol. 7. M. J. Dilworth, E. K. James, J. I. Sprent, and W. E. Newton, eds. Springer, Dordrecht, The Netherlands.

Gupta, G., Parihar, S. S., Ahirwar, N. K., Snehi, S. K., and Singh, V. 2015. Plant growth promoting rhizobacteria (PGPR): Current and future prospects for development of sustainable agriculture. J. Microb. Biochem. Technol. 7:96-102.

Gyaneshwar, P., Hirsch, A. M., Moulin, L., Chen, W. M., Elliott, G. N., Bontemps, C., Estrada-de los Santos, P., Gross, E., Dos Reis, F. B., Sprent, J. I., Young, J. P. W., and James, E. K. 2011. Legume-nodulating betaproteobacteria: Diversity, host range, and future prospects. Mol. PlantMicrobe Interact. 24:1276-1288.

Helms, D., Panella, L., Buddenhagen, L. W., Tucker, C. L., and Gepts, P. L. 1991. Registration of 'California Blackeye 46' cowpea. Crop Sci. 331:1703.

Hirsch, A. M. 1992. Developmental biology of legume nodulation. New Phytol. 122:211-237.

Huang, J., Ji, M., Xie, Y., Wang, S., He, Y., and Ran, J. 2016. Global semi-arid climate change over last 60 years. Clim. Dyn. 46:1131-1150.

Imran, M., Qamar, I. A., Muhammad, S., Mahmood, I. A., Chathha, M. R., Gumani, Z. A., Anjum, A. S., and Shahid, M. N. 2012. Comparison of different cowpea varieties/lines for green fodder and grain yield under rainfed conditions of Islamabad, Pakistan. Sarhad J. Agric. 28:41-46.

Janda, J. M., and Abbott, S. L. 2010. The genus Aeromonas: Taxonomy, pathogenicity, and infection. Clin. Microbiol. Rev. 23:35-73.

Jaramillo, P. M. D., Guimarães, A. A., Florentino, L. A., Silva, K. B., Nóbrega, R. S. A., and Moreira, F. M. S. 2013. Symbiotic nitrogen-fixing bacterial populations trapped from soils under agroforestry systems in the Western Amazon. Sci. Agric. 70:397-404.

Kasana, R. C., Salwan, R., Dhar, H., Dutt, S., and Gulati, A. 2008. A rapid and easy method for the detection of microbial cellulases on agar plates using gram's iodine. Curr. Microbiol. 57:503-507.
Kaur, K., Dattajirao, V., Shrivastava, V., and Bhardwaj, U. 2012. Isolation and characterization of chitosan-producing bacterial from beaches of Chennai, India. Enzyme Res. 2012:421683.

Khan, N., Martínez-Hidalgo, P., Ice, T. A., Maymon, M., Humm, E. A., Nejat, N., Sanders, E. R., Kaplan, D., and Hirsch, A. M. 2018. Antifungal activity of Bacillus species against Fusarium and analysis of the potential mechanisms used in biocontrol. Front. Microbiol. 9:2363.

Khan, N., Maymon, M., and Hirsch, A. M. 2017. Combating Fusarium infection using Bacillus-based antimicrobials. Microorganisms 5:75.

Kumar, K. V., Srivastava, S., Singh, N., and Behl, H. M. 2009. Role of metal resistant plant growth promoting bacteria in ameliorating fly ash to the growth of Brassica juncea. J. Hazard. Mater. 170:51-57.

Kumar, S., Stecher, G., and Tamura, K. 2016. MEGA7: Molecular Evolutionary Genetics Analysis version 7.0 for bigger datasets. Mol. Biol. Evol. 33:1870-1874.

Lafay, B., and Burdon, J. J. 2007. Molecular diversity of legume root-nodule bacteria in Kakadu National Park, Northern Territory, Australia. PLoS One 2: e277.

Langille, M. G., Zaneveld, J., Caporaso, J. G., McDonald, D., Knights, D., Reyes, J. A., Clemente, J. C., Burkepile, D. E., Vega Thurber, R. L., Knight, R., Beiko, R. G., and Huttenhower, C. 2013. Predictive functional profiling of microbial communities using 16S rRNA marker gene sequences. Nat. Biotechnol. 31:814-821.

Langmead, B., Trapnell, C., Pop, M., and Salzberg, S. L. 2009. Ultrafast and memory-efficient alignment of short DNA sequences to the human genome. Genome Biol. 10:R25.

Leite, J., Fischer, D., Rouws, L. F. M., Fernandes-Júnior, P. I., Hofmann, A., Kublik, S., Schloter, M., Xavier, G. R., and Radl, V. 2017. Cowpea nodules harbor non-rhizobial bacterial communities that are shaped by soil type rather than plant genotype. Front. Plant Sci. 7:2064.

Lobo, C. B., Juárez Tomás, M. S., Viruel, E., Ferrero, M. A., and Lucca, M. E. 2019. Development of low-cost formulations of plant growth-promoting bacteria to be used as inoculants in beneficial agricultural technologies. Microbiol. Res. 219:12-25.

Mackenzie, B. W., Waite, D. W., and Taylor, M. W. 2015. Evaluation variation in human gut microbiota profiles due to DNA extraction method and intersubject differences. Front. Microbiol. 6:130.

Malik, K. A., Bilal, R., Mehnaz, S., Rasool, G., Mirza, M. S., and Ali, S. 1997. Association of nitrogen-fixing, plant growth promoting rhizobacteria (PGPR) with kallar grass and rice. Plant Soil 194:37-44.

Martínez-Hidalgo, P., and Hirsch, A. M. 2017. The nodule microbiome: $\mathrm{N}_{2}$-fixing rhizobia do not live alone. Phytobiomes J. 1:70-82.

Mehnaz, S., Baig, D. N., and Lazarovits, G. 2010. Genetic and phenotypic diversity of plant growth promoting rhizobacteria isolated from sugarcane plants growing in Pakistan. J. Microbiol. Biotechnol. 20:1614-1623.

Muhammad, D., Hussain, A., Khan, S. M. B., and Bhatti, M. B. 1993. Variability for green fodder yield and quality in cowpea under rainfed conditions. Pak. Agric. Res. 14:154-158.

Mukhtar, S., Mirza, B. S., Mehnaz, S., Mirza, M. S., Mclean, J., and Malik, K. A. 2018. Impact of soil salinity on the microbial structure of halophyte rhizosphere microbiome. World J. Microbiol. Biotechnol. 34:136.

Mukhtar, S., Shahid, I., Mehnaz, S., and Malik, K. A. 2017. Assessment of two carrier materials for phosphate solubilizing biofertilizers and their effect on growth of wheat (Triticum aestivum). Microbiol. Res. 205:107-117.

Olsen, S. R., Cole, C. V., Watanabe, F. S., and Dean, L. A. 1954. Estimation of available phosphorus in soils by extraction with sodium bicarbonate. USDA Circ. 939:1-19.

Pérez-Miranda, S., Cabirol, N., George-Téllez, R., Zamudio-Rivera, L. S., and Fernández, F. J. 2007. O-CAS, a fast and universal method for siderophore detection. J. Microbiol. Methods 70:127-131.

Phillips, R. D., McWatters, K. H., Chinnan, M. S., Hung, Y. C., Beuchat, L. R., Sefa-Dedeh, S., Sakyi-Dawson, E., Ngoddy, P., Nnamyelugo, D., Enwere, J., Komey, N. S., Liu, K., Mensa-Wilmot, Y., Nnanna, I. A., Okeke, C., Prinyawiwatkul, W., and Saalia, F. K. 2003. Utilization of cowpeas for human food. Field Crops Res. 82:193-213.

Pikovskaya, R. 1948. Mobilization of phosphorus in soil in connection with vital activity of some microbial species. Mikrobiologiya 17:362-370.

Pruitt, K. D., Tatusova, T., and Maglott, D. R. 2005. NCBI Reference Sequence (RefSeq): A curated non-redundant sequence database of genomes, transcripts and proteins. Nucleic Acids Res. 33:D501-D504.

Pule-Meulenberg, F., Belange, A. K., Krasova-Wade, T., and Dakora, F. D. 2010. Symbiotic functional and bradyrhizobial biodiversity of cowpea (Vigna unguiculata L. Walp.) in Africa. BMC Microbiol. 10:89. 
Sadasivam, S., and Manickam, A. 1992. Assay for hydrogen cyanide detection. Pages 204-205 in: Biochemical Methods for Agricultural Sciences. Wiley Eastern Ltd., New Delhi, India.

Saima, M. K., and Roohi, I. Z. A. 2013. Isolation of novel chitinolytic bacteria and production optimization of extracellular chitinase. J. Genet. Eng. Biotechnol. 11:39-46.

Saitou, N., and Nei, M. 1987. The neighbor-joining method: A new method for reconstructing phylogenetic trees. Mol. Biol. Evol. 4:406-425.

Salter, S. J., Cox, J. M., Turek, E. M., Calus, S. T., Cookson, W. O., Moffatt, M. F., Turner, P., Parkhill, J., Lornan, N. J., and Walker, A. W. 2014. Reagent and laboratory contamination can critically impact sequenced-based microbiome analyses. BMC Biol. 12:87.

Sanders, W. E., Jr., and Sanders, C. C. 1997. Enterobacter spp.: Pathogens poised to flourish at the turn of the century. Clin. Microbiol. Rev. 10:220-241.

Sawada, H., Kuykendall, L. D., and Young, J. M. 2003. Changing concepts in the systematics of bacterial nitrogen-fixing legume symbionts. J. Gen. Appl. Microbiol. 49:155-179.

Sawana, A., Adeolu, M., and Gupta, R. S. 2014. Molecular signatures and phylogenomic analysis of the genus Burkholderia: Proposal for division of this genus into the emended genus Burkholderia containing pathogenic organisms and a new genus Paraburkholderia, gen. nov. harboring environmental species. Front. Genet. 5:429.

Schwartz, A. R., Ortiz, I., Maymon, M., Herbold, C. W., Fujishige, N. A., Vijanderan, J. A., Villella, W., Hanamoto, K., Diener, A., Sanders, E. R., DeMason, D. A., and Hirsch, A. M. 2013. Bacillus simplex-A little known PGPB with anti-fungal activity-alters pea legume root architecture and nodule morphology when coinoculated with Rhizobium leguminosarum bv. viciae. Agronomy (Basel) 3:595-620.

Shahid, I., Rizwan, M., Baig, D. N., Saleem, R. S., Malik, K. A., and Mehnaz, S. 2017. Secondary metabolites production and plant growth promotion by Pseudomonas chlororaphis subsp. aurantiaca strains isolated from cotton, cactus and para grass. J. Microbiol. Biotechnol. 27:480-491.

Shetty, A. A., Magadum, S., and Managanvi, K. 2013. Vegetables as sources of antioxidants. J. Food Nutr. Disord. 2:2.

Shi, B., Chang, M., Martin, J., Mitreva, M., Lux, R., Klokkevold, P., Sodergren, E., Weinstock, G. M., Haake, S. K., and Li, H. 2015. Dynamic changes in the subgingival microbiome and their potential for diagnosis and prognosis of periodontitis. MBio 6:e01926-14.

Sierra, G. 1957. A simple method for the detection of lipolytic activity of micro-organisms and some observations on the influence of the contact between cells and fatty acid substrates. Antonie Leeuwenhoek. 23:15-22.

Sigmon, J. 2008. The starch hydrolysis test. American Society for Microbiology. https://www.asmscience.org/content/education/imagegallery/image.3172
Steenkamp, E. T., Stepkowski, T., Przymusiak, A., Bothaa, W. J., and Law, I. J. 2008. Cowpea and peanut in southern Africa are nodulated by diverse Bradyrhizobium strains harboring nodulation genes that belong to the large pantropical clade common in Africa. Mol. Phylogenet. Evol. 48:1131-1144.

Sturz, A., Christie, B., Matheson, B., and Nowak, J. 1997. Biodiversity of endophytic bacteria which colonize red clover nodules, roots, stems and foliage and their influence on host growth. Biol. Fertil. Soils 25:13-19.

Sulieman, S., and Tran, L. P. 2014. Symbiotic nitrogen fixation in legume nodules: Metabolism and regulatory mechanisms. Int. J. Mol. Sci. 15:19389-19393.

Tamura, K., Nei, M., and Kumar, S. 2004. Prospects for inferring very large phylogenies by using the neighbor-joining method. Proc. Natl. Acad. Sci. U.S.A. 101:11030-11035.

Tani, C., Sasakawa, H., and Takenouchi, K. 2003. Isolation of endophytic Frankia from root nodules of Casuarina equisetifolia and infectivity of the isolate to host plants. Soil Sci. Plant Nutr. 49:137-142.

Tindal, B. J., Sutton, G., and Garrity, G. M. 2017. Enterobacter aerogenes Hormaeche and Edwards 1960 (Approved Lists 1980) and Klebsiella mobilis Bascomb et al. 1971 (Approved Lists 1980) share the same nomenclatural type (ATCC 13048) on the Approved Lists and are homotypic synonyms, with consequences for the name Klebsiella mobilis Bascomb et al. 1971 (Approved Lists 1980). Int. J. Syst. Evol. Microbiol. 67:502-504.

Trinidad, T. P., Mallillin, A. C., Loyola, A. S., Sagum, R. S., and Encabo, R. R. 2010. The potential health benefits of legumes as a good source of dietary fibre. Br. J. Nutr. 103:569-574.

Velázquez, E., Martínez-Hidalgo, P., Carro, L., Alonso, P., Peix, A., Trujillo, M. E., and Martínez-Molina, E. 2013. Nodular endophytes: An untapped diversity. Pages 215-236 in: Beneficial Plant Microbial Interactions: Ecology and Applications. M. B. Rodelas González and J. Gonzalez-Lopez, eds. CRC Press, Boca Raton, FL, U.S.A.

Walkley, A., and Black, I. A. 1934. An examination of Degtjareff method for determining soil organic matter and a proposed modification of the chromic acid titration method. Soil Sci. 37:29-38.

Watanabe, F., and Olsen, S. 1965. Test of an ascorbic acid method for determining phosphorus in water and $\mathrm{NaHCO} 3$ extracts from the soil. Soil Sci. 29:677-678.

Wattenburger, C. J., Halverson, L. J., and Hofmockel, K. S. 2019. Agricultural management affects root-associated microbiome recruitment over maize development. Phytobiomes. 3:260-272.

Weisburg, W. G., Barns, S. M., Pelletier, D. A., and Lane, D. J. 1991. 16S ribosomal DNA amplification for phylogenetic study. J. Bact. 173:697-703.

Xu, L., Zhang, Y., Wang, L., Chen, W., and Wei, G. 2014. Diversity of endophytic bacteria associated with nodules of two indigenous legumes at different altitudes of the Qilian Mountains in China. Syst. Appl. Microbiol. 37:457-465. 